\title{
Pisidia longimana (Risso, 1816), a junior synonym of $P$. bluteli (Risso, 1816) (Crustacea: Decapoda: Anomura: Porcellanidae) and a species distinct from $P$. longicornis (Linnaeus, 1767)
}

\author{
Luciane Augusto de Azevedo Ferreira ${ }^{1,2}$ \& Marcos Tavares ${ }^{1,3}$ \\ 1 Universidade de São Paulo (USP), Museu de Zoologia (MZUSP). São Paulo, SP, Brasil. \\ 2 ORCID: http://orcid.org/0000-0003-1683-9962. E-mail: lucianeaaf@gmail.com \\ 3 ORCID: http://orcid.org/0000-0002-7186-5787.E-mail:mdst@usp.br
}

\begin{abstract}
Pisidia longimana (Risso, 1816) and P. bluteli (Risso, 1816), both described from Nice, France, have been considered each other's synonyms or have been validated depending on successive taxonomic opinions. The validity of both in respect to P. Iongicornis (Linnaeus, 1767) has also been contradicted a number of times. The current lack of clarity in the use of the names $P$. Iongicornis, P. longimana and $P$. bluteli has resulted in nomenclatural instability, but also in unreliability and miscommunication as regards the available ecological and distributional information. The validity of $P$. bluteli and $P$. longimana is revisited herein based on a large number of specimens (241 males, 190 females and 33 juveniles) from many different localities. The latter species is confirmed as a junior synonym of the former, whereas $P$. bluteli and $P$. longicornis are herein considered separate species. Diagnostic characters and morphological variations are discussed and illustrated.
\end{abstract}

Key-Words. Biodiversity; Eastern Atlantic; Mediterranean; Porcelain crabs.

\section{INTRODUCTION}

The worldwide genus Pisidia Leach, 1820, currently consists of 15 species distributed across the tropical and subtropical zones of the eastern Pacific, western and eastern Atlantic and IndoWest Pacific Oceans, and Mediterranean and Black Seas (Haig, 1978; Osawa \& McLaughlin, 2010; Dong \& Li, 2014; WoRMS, 2020).

Three species are currently considered valid from the eastern Atlantic and Mediterranean and Black Seas basins: Pisidia longicornis (Linnaeus, 1767), P. bluteli (Risso, 1816) and P. longimana (Risso, 1816) (Osawa \& McLaughlin, 2010). However, P. longimana and P. bluteli have been lumped and split alternately with each successive taxonomic opinion, and the validity of both in respect to $P$. longicornis has also been contradicted a number of times (Zariquiey-Álvarez, 1951; Holthuis, 1961; García-Raso, 1987; d'Udekem d'Acoz, 1995, 1999; Koukouras et al., 2002; Osawa \& McLaughlin, 2010). Thus, the current lack of clarity in the use of the names P. longicornis, P. longimana and $P$. bluteli has resulted in nomenclatural instability, but also in unreliability and miscommunica- tion of the available ecological and distributional information.

An ongoing phylogenetic analysis of the genus Pisidia and the examination of 241 males, $190 \mathrm{fe}-$ males and 33 juveniles from many different localities in the collections of the National Museum of Natural History, Smithsonian Institution (USNM) and Museu de Zoologia, Universidade de São Paulo (MZUSP), prompted us to revisit the validity of $P$. bluteli and $P$. longimana. The latter species is confirmed as a junior synonym of the former, whereas P. bluteli and P. longicornis are herein considered two separate species. Diagnostic characters and morphological variations are discussed and illustrated.

\section{MATERIAL AND METHODS}

Abbreviations used include: $\mathrm{cl}$, carapace length, taken from the front to the posterior median margin of the carapace; $\mathrm{CW}$, carapace width, taken at the level of its widest point; $\mathrm{P} 1$, cheliped (pereopod 1); P2-P4, pereopods 2 to 4; St, station.

The ecological notes and distributional ranges were compiled by d'Udekem d'Acoz (1999) 
separately for $P$. bluteli and $P$. longimana and are herein combined.

Bibliographic references in the synonymic list are not exhaustive, being limited only to taxonomic works including nomenclatural acts and taxonomical opinions.

\section{RESULTS AND DISCUSSION}

\section{Family Porcellanidae Haworth, 1825 Genus Pisidia Leach, 1820}

Type species: Cancer longicornis Linnaeus, 1767

\section{Pisidia bluteli (Risso, 1816) (Figs. 1A-O)}

Porcellana bluteli Risso, 1816: 67, pl. 1, fig. 7 [type locality: Nice, France]; Zariquiey-Álvarez, 1951: 131, figs. 1, 2A-D.

Porcellana longimana Risso, 1816: 68 [type locality: Nice, France].

Pisidia bluteli - Haig, 1960: 209; Holthuis, 1961: 37, figs. 12a, d, 13a; Zariquiey-Álvarez, 1968: 290, 291, figs. 94e, 103a, e, f; Manning \& Števčić, 1982: 297; García-Raso, 1987: 277, fig. 7; Števčić, 1990: 229; Koçak et al., 2010: 340.

Pisidia longimana - Holthuis, 1961: 40, figs. 12b, e, 13b; Zariquiey-Álvarez, 1968: 291, 292, fig. 103b; Manning \& Števčić, 1982: 297; García-Raso, 1987: 277, figs. 1, 3-5; Koukouras et al., 2002: 451, figs. 2b-4b; Koçak et al., 2010: 340.

Pisidia forma bluteli - d'Udekem d'Acoz, 1999: 170.

Pisidia forma longimana - d'Udekem d'Acoz, 1999: 170.

Material examined: Spain: Cádiz, Bay of Cádiz, Los Lastres, east part of Bay of Cádiz, 29 Oct. 1974, 5 m, 1 male, 1 ovigerous female (USNM 258280); Bay of Cádiz, just northwest of harbor entrance of Cádiz, 29 Oct. 1974, 8 to 10 m, 1 male (USNM 258282); Bay of Cádiz, east part of Bay of Cádiz near Bajo de Las Cabezuelas, sand dune on a small cape, 30 Oct. 1974, 2.5 m, 1 male (USNM 258283). Italy: Sicily, between Mazara del Vallo and Capo Guanitola, 37 $34^{\prime} 36^{\prime \prime} \mathrm{N}, 12^{\circ} 39^{\prime} 00^{\prime \prime} \mathrm{E}$, St. Sic 85-1, 0.5 m, R.B. Manning \& C. Froglia coll., 1985, 1 male, 1 female (USNM 205775); Scogliere Falconara M. (Ancona), C. Froglia coll., 11 May 1973, 0.5 m, 2 males, 1 female, 3 ovigerous females (USNM 205865); Triestre, Grado, 10 m, C. Froglia coll., 16 Jan. 1974, 5 males, 2 females (USNM 152180); Golfo di Manfredonia, $41^{\circ} 25^{\prime} 18^{\prime \prime} \mathrm{N}$, $16^{\circ} 13^{\prime} 30^{\prime \prime} \mathrm{E}, 15 \mathrm{~m}, \mathrm{C}$. Froglia et al. coll., 06 Jul. 1974, 8 males, 11 ovigerous females, 1 intersex (USNM 152181). Slovenia: Portoroz, 17 m, 11 Sep. 1970, 3 males, 2 females, 1 ovigerous female (USNM 1278008); Portoroz, Obala, 26 Aug. 1971, 2 males, 1 female, 5 ovigerous females (USNM 1278011). Croatia: Cervar, near Porec, in Mytilus beds, 3 males (USNM 1277826); Ibidem, 4 males, 12 females (USNM 1277824); Dalmatia, under stones, from Mytilus beds, 9 males, 7 ovigerous females
(USNM 1277834); Pula, Pomer Bei, from Mytilus beds, 18 males, 25 females (USNM 1277836). Montenegro: Sveti Juan, in bryozoans, 35 to 40 m, 28 Aug. 1990, 1 male (USNM 1277830). Turkey: Woflzmir, $37^{\circ} 25^{\prime} \mathrm{N}$, $26^{\circ} 40^{\prime} \mathrm{E}, 29$ to $36.5 \mathrm{~m}$, M.J. Sweeney coll., 19 Jun. 1973, 2 males (USNM 150831). Tunisia: Tunis, La Marsa, public beach at Marsa Plage, St. 211C, from Posidonia roots, M.L. Jones coll., 21 Aug. 1973, 1 ovigerous female (USNM 1277827); La Marsa, public beach at Marsa Plage, 2 m, R.B. Manning et al. coll., 29 Jul. 1972, 1 male, 1 female (USNM 265991); La Marsa, public beach at Marsa Plage, 0 to $2 \mathrm{~m}$, from sabellarid colonies; R.B. Manning \& R. Brown coll., 10 Aug. 1972, 22 juveniles (USNM 1278013); Salammbo, Punic Port, R.B. Manning \& L.B. Holthuis coll., 04 Oct. 1972, 9 males, 3 females (USNM 265992); Salammbo, south port along entrance channel to Punic Port, L.B. Holthuis \& R.B. Manning coll., 06 Oct. 1972, 1 male (USNM 265997); Punic Port, 24 Apr. 1974, 1 female (USNM 1277832); Salammbo, flat north of and outside of North Punic Port, M.L. Jones coll., 21 Aug. 1973, 2 males, 3 females (USNM 1278014); Salammbo, North Punic Port, in channel, St. 206D, algae wash, M.L. Jones coll., 18 Aug. 1973, 2 males (USNM 1278016); Salammbo, near Port Punic, St. 207B, grass flats, algae wash, M.L. Jones coll., 19 Aug. 1973, 5 males, 2 females, 11 juveniles (USNM 1278019); Salammbo, grass flats adjacent to northern Punic Port, St. 207B, algae wash, M.L. Jones coll., 19 Aug. 1973, 3 males, 1 intersex (USNM 1278020); Raquad, off first public beach, 2 to $4 \mathrm{~m}$, R.B. Manning et al. coll., 21 Jan. 1973, 1 male (USNM 265999); Raquad, 12 km north of WW II Bunker at beach proper adjacent to mouth of canal extending to beach, L.B. Holthuis \& R.B. Manning coll., 10 Oct. 1972, 1 male (USNM 265993); Korbous, isolated beach between Sidi Rais and Arn Oktor, R.B. Manning et al. coll., 30 May 1973, 1 male (USNM 265998); off Cap Samart Proper, 3 to 5 m, R.B. Manning coll., 14 Jan. 1973, 3 males, 3 females, 3 ovigerous females (USNM 265994); Sidi Bou Said, south of Yatch Basin, R.B. Manning \& C. Froglia coll., 29 May 1973, 11 males, 2 females, 5 ovigerous females (USNM 265995); Sidi Bou Said, just south of Yatch Basin, R.B. Manning \& L.B. Holthuis coll., 05 Oct. 1972, 2 females (USNM 265996); Sidi Bou Said, in Yatch Club Harbor, R.B. Manning \& C. Froglia coll., 23 May 1973, 13 males, 2 females, 9 ovigerous females (USNM 265798); Sidi Ali El Mekki, west edge of Lac de Porta Farina, behind shore about $5 \mathrm{~km}$ from beach (salt lake), St. RBM TUN-27, R. Brown et al. coll., 13 Aug. 1972, 2 males, 1 ovigerous female (USNM 1277844); St. 251B, R.B. Manning coll., 28 Oct. 1973, 4 males, 2 females (USNM 1278010); St. 17, R.B. Manning coll., 4 males, 2 ovigerous females (USNM 1277838); St. 23A, R.B. Manning coll., 7 males, 6 females, 2 ovigerous females (USNM 1277839); St. ALG-9A, R.B. Manning coll., 09 Mar. 1974, 2 males, 1 ovigerous female (USNM 1278009); St. 23A, R.B. Manning coll., 1 female (USNM 1278012); St. 211B, R.B. Manning coll., 1 male, 2 females, 1 intersex (USNM 1278015); St. 210, R.B. Manning coll., 4 males, 1 ovigerous female (USNM 1278017); St. 207B, R.B. Manning coll., 4 males (USNM 1278018); St. 211C, R.B. Manning coll., 21 Aug. 1973, 9 males, 8 females, 2 ovig- 

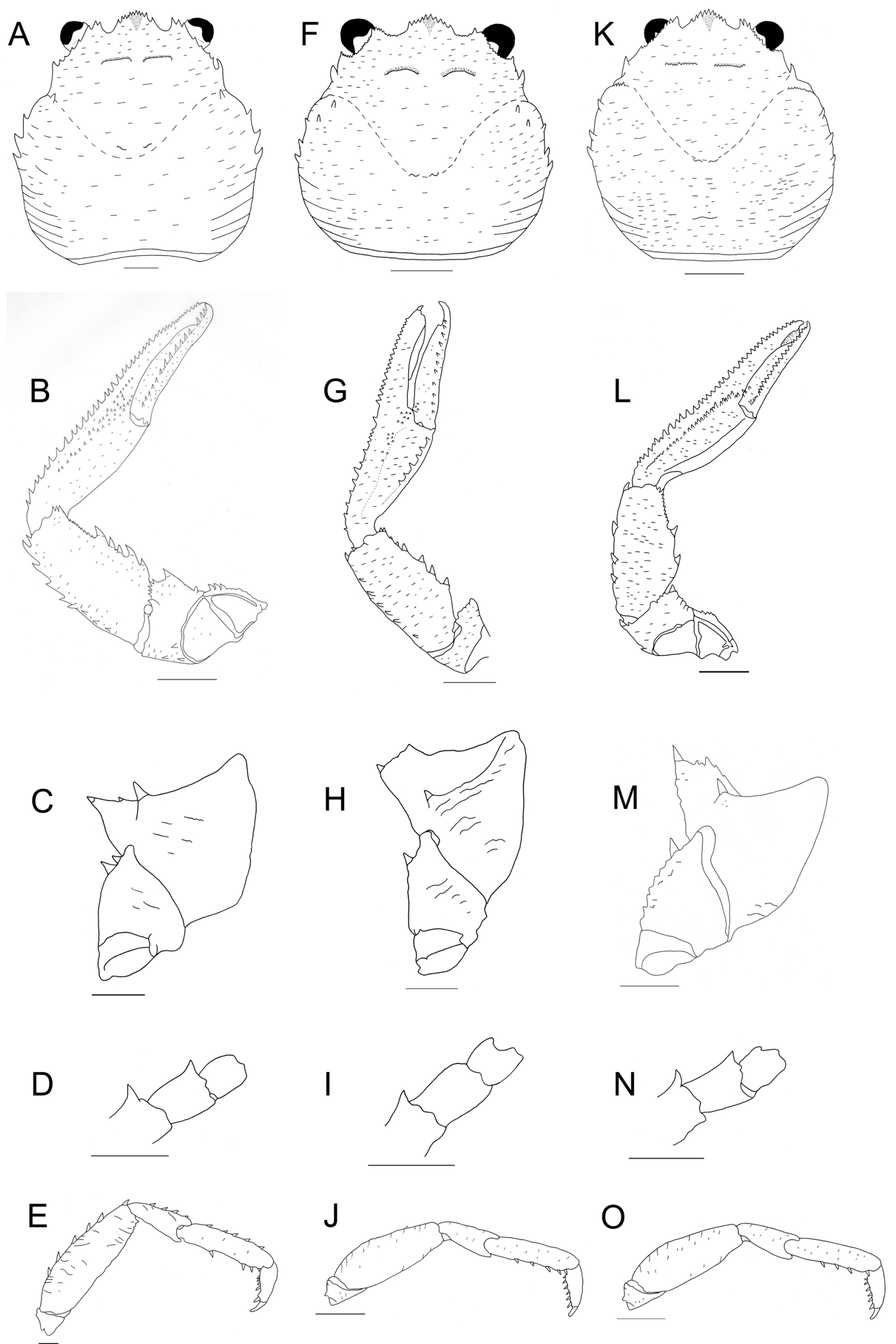

Figure 1. (A-0) Pisidia bluteli (Risso, 1816). (A-E)" bluteli type", female, cl $4.6 \mathrm{~mm}, \mathrm{cw} 4.3 \mathrm{~mm}$ (USNM 1278011). (F-J) "bluteli-longimana type", female, cl $4.4 \mathrm{~mm}, \mathrm{cw} 4.3 \mathrm{~mm}$ (USNM 1278011). (K-0) "Iongimana type", female, cl $4.8 \mathrm{~mm}$, cw $4.7 \mathrm{~mm}$ (USNM 205865). (A, F, K) carapace, dorsal view (B, G, L) left P1, dorsal view. (C, H, M) left ischial and meral P1, ventral view; $(D, I, N)$ right antenna, dorsal view; $(E, J, 0)$ left P2, lateral view. Scale bars: $(A, B, E-G, J-L, 0)=1 \mathrm{~mm} ;(C, D, H, I, M, N)=0.5 \mathrm{~mm}$. 
erous females, 1 intersex (USNM 1278021); St. 38B, R.B. Manning coll., 1 female (USNM 1278023); St. 39B, R.B. Manning coll., 25 Aug. 1972, 1 male (USNM 1278024); St. 176B, R.B. Manning coll., 05 Jul. 1973, 1 ovigerous female (USNM 1278025); St. 47A, R.B. Manning coll., 2 males, 1 female (USNM 1278026).

Comparative material examined: Pisidia longicornis (Linnaeus, 1767): Wales: Caernavonshire, Abedaron Bay, north of Gales, O.D. John \& F.C. Fraser coll., 24 Jul. 1936, 2 males, 2 ovigerous females. (USNM 156435). England: Drake's Island, Plymouth Sound, O. Hartman coll., 16 Aug. 1939, 2 intersex (USNM 1256039); London, Channel Islands, E. Lovett coll., 5 males (USNM 6560). Germany: Helgoland, Royal Biological Station, Austern bânke der Nordsee, 1890, 3 males, 1 ovigerous female (USNM 19907). France: Chausey Islands, R.B. Manning \& A. Crosnier coll., 27 Aug. 1996, 24 males, 15 females, 11 ovigerous females, 1 intersex (USNM 283078); R.B. Manning \& A. Crosnier coll., 27 Aug. 1996, 2 males, 2 females, 1 ovigerous female (USNM 1256055); $48^{\circ} 53^{\prime} \mathrm{N}, 01^{\circ} 50^{\prime} \mathrm{W}$, north side of islands, Manning et al. coll., 27 Aug. 1992, 5 males, 3 ovigerous females (USNM 264683); north side of Chausey Island, Manning et al. coll., 29 Aug. 1992, 3 males (USNM 264683); Manning et al. coll., 28 Aug. 1992, 5 males, 1 female (USNM 264654); Granville et al. coll., Aug. 1996, 2 males, 2 females (MZUSP 18730); 2 males (MZUSP 25286). Spain: Ria de Arousa, St. 1288, 04 Jul. 1963, 2 males, 2 ovigerous females (USNM 121833); St. 1472, 23 Jul. 1964, 1 male (USNM 121834); St. 1472, 23 Jul. 1964, 1 male (USNM 121835); Isla de Arousa, 0.3 km north-northeast of Punta Campelo, $42^{\circ} 34,5^{\prime} \mathrm{N}, 08^{\circ} 52,7^{\prime} \mathrm{W}$, F. Ponte coll., 18 Jul. 1964, 18 m, 2 males (USNM 121837); $42^{\circ} 34,7^{\prime} \mathrm{N}, 08^{\circ} 52,3^{\prime} \mathrm{W}$, St. 1607, F. Ponte coll., 20 Jul. 1964, 1 male (USNM 121840); $1.5 \mathrm{~km}$ north-northeast of Punta do Campelo, $42^{\circ} 35,2^{\prime} \mathrm{N}, 08^{\circ} 52,8^{\prime} \mathrm{W}$, St. 1606, F. Ponte coll., 20 Jul. 1964, 30 to 40 m, 2 males (USNM 121839); between Lobeira de Cambados and Goldferna, F. Ponte coll., 30 Jul. 1964, 19 m, 1 male (USNM 121847); 30 Jul. 1964, 19 m, 9 males, 1 female, 1 ovigerous female (USNM 121846); 0.2 km northeast of Jidoiro Pedregoso, $42^{\circ} 32,6^{\prime} \mathrm{N}, 08^{\circ} 54,8^{\prime} \mathrm{W}$, St. 1924, F. Ponte coll., 12 Aug. 1964, $5 \mathrm{~m}, 1$ female (USNM 121850); O Grove, $2.2 \mathrm{~km}$ southeast of Punta Canela, $42^{\circ} 26,6^{\prime} \mathrm{N}, 08^{\circ} 27,2^{\prime} \mathrm{W}$, St. 1841, J. Cambeira coll., 06 Aug. 1964, 55 to 65 m, 1 ovigerous female (USNM 121848); $0.2 \mathrm{~km}$ southeast of Benencia south lighthouse, $42^{\circ} 35,5^{\prime} \mathrm{W}-08^{\circ} 52,5^{\prime} \mathrm{W}$, F. Ponte coll., 18 Jul. 1964, 20 to $30 \mathrm{~m}, 1$ male (USNM 121836); $0.6 \mathrm{~km}$ northeast of Punta Cabio, $42^{\circ} 35,0^{\prime} \mathrm{N}, 08^{\circ} 55,3^{\prime} \mathrm{W}$, St. 1631 , F. Ponte coll., 22 Jul. 1964, 7 m, 1 male (USNM 121844); $42^{\circ} 35,4^{\prime} \mathrm{N}$, $08^{\circ} 54,8^{\prime} \mathrm{W}$, F. Ponte coll., 04 Aug. 1964, 15 to $20 \mathrm{~m}, 1$ male (USNM 121849); $42^{\circ} 35,4^{\prime} \mathrm{N}, 08^{\circ} 52,6^{\prime} \mathrm{W}$, F. Ponte coll., 20 Jul. 1964, 30 m, 1 ovigerous female (USNM 121838); $0.3 \mathrm{~km}$ southwest of Los Mezos Light, $42^{\circ} 30,8^{\prime} \mathrm{N}$, 0855,7'W, St. 1633 (F11), F. Ponte coll., 22 Jul. 1964, 12 m, 1 ovigerous female (USNM 121841); St. 1633 (F11), F. Ponte coll., 22 Jul. 1964, 12 m, 1 male (USNM 121842); $0.4 \mathrm{~km}$ of Los Mezos Light, $42^{\circ} 30,7^{\prime} \mathrm{N}$, $08^{\circ} 56,0^{\prime}$ W, St. 1634 (F12), F. Ponte coll., 22 Jul. 1964, 18 to $22 \mathrm{~m}, 2$ females (USNM 121843). Portugal:
Algarve, Faro, south coast of Portugal, Zariquiey-Álvarez coll., 04 Nov. 1974, 9 to $10 \mathrm{~m}$, offshore, 7 males, $1 \mathrm{fe-}$ male, 1 ovigerous female (USNM 258279); ZariquieyÁlvarez coll., 04 Nov. 1974, 16 m, 3 males, 1 ovigerous female (USNM 258279); Armação de Pera, south coast, 01 Nov. 1974, 1 male (USNM 258268).

Habitat: Pisidia bluteli has been reported from under rocks, hard bottoms, detritic bottoms, sabellariid colonies, calcareous algae, oyster and Mytilus beds, and rhizomes of Posidonia (d'Udekem d'Acoz, 1999 and references therein).

Distribution: This species is known from the Atlantic coasts of Spain, Portugal and Morocco, and the entire Mediterranean and Black Seas, between the tidal mark down to $20 \mathrm{~m}$ (d'Udekem d'Acoz, 1999 and references therein).

Remarks: Pisidia bluteli and P. longimana (both as Porcellana) were briefly described from Nice, France by Risso (1816). Pisidia bluteli was crudely illustrated, whereas no illustration of $P$. longimana was given.

Pisidia bluteli was generally regarded as a junior synonym of P. longicornis (Linnaeus, 1776), until ZariquieyÁlvarez (1951) provided evidence that both species were morphologically distinct. While agreeing with ZariquieyÁlvarez, Holthuis (1961) argued that not only was P. bluteli valid, but so was $P$. longimana, and he therefore removed the latter species from the synonymy with $P$. longicornis.

Holthuis' (1961) view, however, was challenged by the observations of Manning \& Števčić (1982), who, without further details, commented that some specimens from the Piran Gulf (northern Adriatic Sea) showed intergradations between P. bluteli and P. longimana. García-Raso (1987) went farther and moved P. bluteli and P. longimana back into the synonymy with $P$. longicornis. Conversely, Koukouras et al. (2002), once again considered P. bluteli and $P$. longimana as being distinct from each other and from $P$. longicornis.

Arguments in favor of splitting $P$. bluteli from $P$. longima$n a$ are essentially those of Holthuis (1961): (1) the orbital margin shows a row of spines in P. bluteli, whereas the orbital margins are usually crenulate or minutely serrate, never spinous in P. longimana; (2) there are several distinct spines on the dorsal surface of the carapace in P. bluteli, whereas the carapace spines are smaller and in P. longimana larger specimens, hardly visible; (3) the antennal basis-ischium and merus have a distinct spine at the distal end of the mesial margin in P. bluteli, whereas the antennal merus bears no spine, although a distinct spine is present in the antennal basis-ischium in P. longimana; (4) numerous spinules, arranged in more or less distinct longitudinal rows, are found on the dorsal surface of the carpus and the palm in P. bluteli, whereas the dorsal surface of the carpus and palm are smooth, although in the juveniles they may be provided with a median longitudinal row of granules or spinules, in P. longimana; (5) a row of slender spinules usually is present along the lateral margin of the carpus in P. bluteli, whereas the lateral margin of the 
carpus is smooth in the adults, but may be provided with spinules in the juveniles in P. longimana; and (6) numerous strong dorsal spines are present on the merus, carpus and propodus of the walking legs in P. bluteli, whereas the carpus and merus of the walking legs do not show a row of spinules, although very few short and blunt granules or spinules may sometimes be observed on the merus in P. longimana (Holthuis, 1961). Additionally, Koukouras et al. (2002) submitted that P. bluteli and P. longimana could be further differentiated in that the branchial region, behind the cervical groove, is provided with 2 or more spines (rarely 1 ) in $P$. bluteli, whereas, in contrast, the branchial region bears 0 to 1 spines (rarely 2) spines in P. longimana. However, García-Raso (1987) opined that the characters used by Holthuis (1961) do not allow for distinguishing between $P$. longicornis, $P$. longimana and $P$. bluteli for intermediate forms in which all possible combinations of the purportedly distinguishing characters are commonly found, sometimes even in the same specimen. Consequently, García-Raso (1987) concluded that P. bluteli and $P$. longimana should be sunk into the synonymy with P. longicornis (see also d'Udekem d'Acoz, 1995, 1999).The

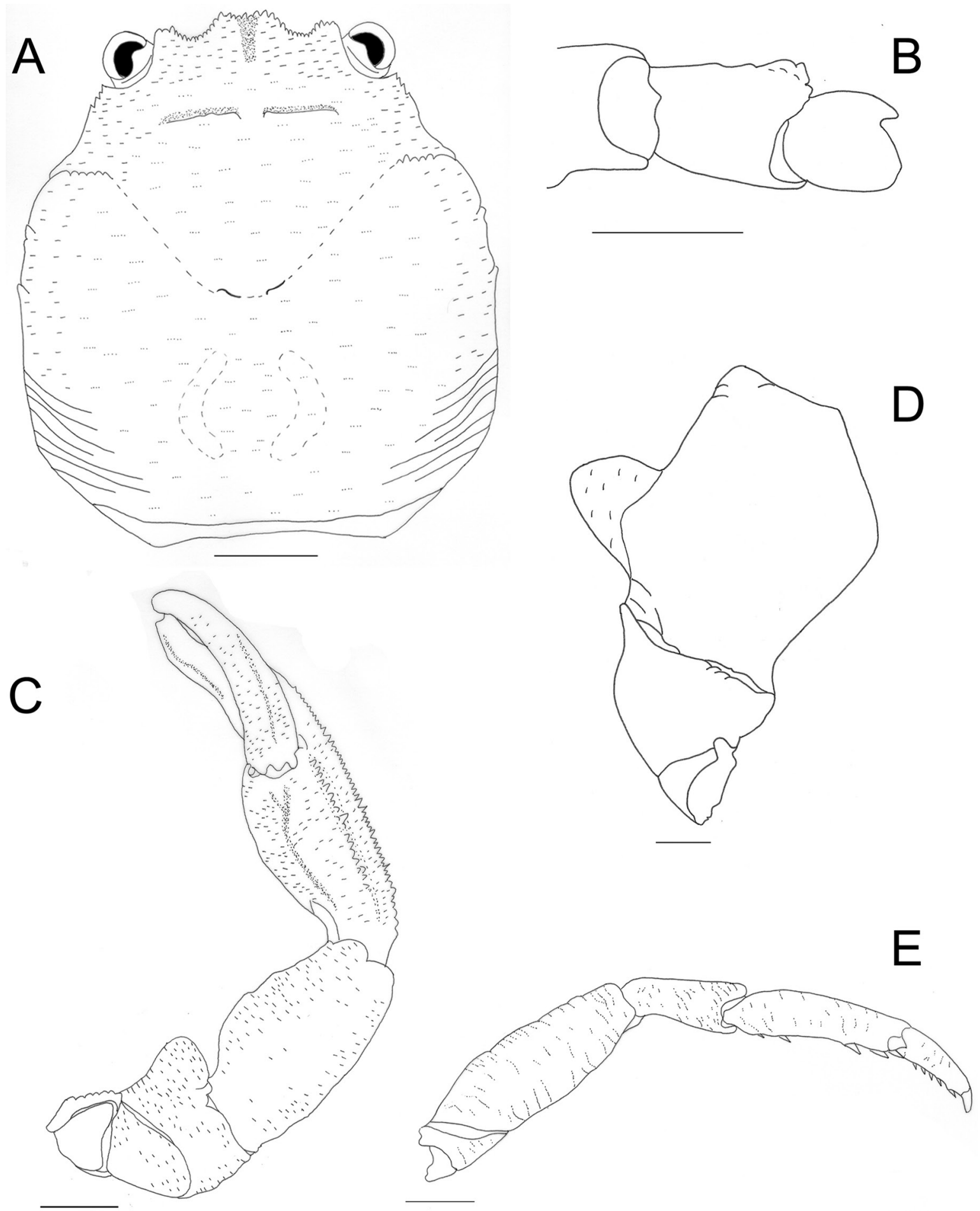

Figure 2. (A-E) Pisidia longicornis (Linnaeus, 1767), female, cl 5.1, cw 5.1 (MZUSP 18730). (A) carapace, dorsal view; (B) right antenna, dorsal view; (C) left P1, dorsal view; (D) left ischial and meral P1, ventral view; (E) left P2, lateral view. Scale bars: $(A, C, E)=1 \mathrm{~mm} ;(B, D)=0.5 \mathrm{~mm}$. 
large number of specimens examined herein from the collections of the USNM and MZUSP lends support to the view that $P$. bluteli and $P$. longimana are synonyms. The purportedly diagnostic characters for distinguishing between $P$. bluteli and $P$. longimana actually intergrade between specimens, even from the same locality. For instance, the specimen USNM 1278011 (Fig. 1F-J) presents the "bluteli type" of carapace with epibranchial spines (Fig. 1F) and the P1 carpus bears a row of spines laterally and mesially (Fig. 1G), but also presents the "longimana type" of $\mathrm{P} 1$ ischium with one ventrodisto-mesial spine (Fig. 1H); antenna merus without a spine mesially (Fig. 1I); and P2-P4 dorsal spines absent (Fig. 1J).

The morphological variations in $P$. bluteli include: (1) carapace with epibranchial spines either well developed, rudimentary or absent (Figs. 1A, F, K); (2) mesial spine on antennal merus either present or absent (Figs. 1D, I, N); (3) one or two ventrodisto-mesial spines on the $\mathrm{P} 1$ ischium (Figs. $1 \mathrm{C}, \mathrm{H}, \mathrm{M}$ ); (4) two or a row of mesial spines on the $\mathrm{P} 1$ carpus (Figs. $1 \mathrm{~B}, \mathrm{G}, \mathrm{L}$ ); three or a row of lateral spines on the P1 carpus (Fig. 1B, G, L); (5) presence or absence of a row of spines on the dorsal surface of P2, P3 and P4 (Figs. 1E, J, O).

Likewise, the characters proposed by Koukouras et al. (2002) clearly overlap with each other and therefore, cannot be used to distinguish among P. longicornis, P. bluteli and $P$. longimana. However, three diagnostic characters differentiate $P$. longicornis from $P$. bluteli: (1) P. longicornis (as already noticed by Holthuis, 1961) presents inconspicuous or absent spinulation compared to P. bluteli, whose spines in the carapace, antenna and $P 1$ are always well-developed (Figs. 1A-O; 2A-E); (2) P. longicornis males present the major P1 broader and swollen, whereas in $P$. bluteli the P1 is long, slender and slightly flattened (present study); (3) the front in P. longicornis presents a deep longitudinal groove in the median lobe (so that the median lobe seems to be divided into two), whereas $P$. bluteli presents three conspicuous lobes, with the longitudinal one shallow and poorly visible (present study) (Figs. 1A, F, K; 2A).

Pisidia longicornis s. str. is known from the Atlantic coast of Europe, from south Norway to Portugal, as well as from the Mediterranean Sea, where it inhabits greater depths, between 30 and 100 m (d'Udekem d'Acoz, 1999). Its record from the west African coast, from Mauritania to Angola (Chace, 1956) deserves further investigation.

\section{ACKNOWLEDGMENTS}

We gratefully thank Rafael Lemaitre (USNM) for granting access to the collection under his responsibility and for providing working space. Thanks also extend to Karen Reed (USNM) for her kind assistance throughout the execution of this work. We are also grateful to Christopher B. Boyko (American Museum of of Natural History, New York) for helpful suggestions. LAAF thanks CNPq (372489/2019-2). MT thanks CNPq (303122/2016-1) for supporting studies on the systematics of decapod crustaceans.

\section{REFERENCES}

Chace, F.A. 1956. Porcellanid crabs. Expédition 0céanographique Belge dans les eauxs côtières africaines de l'Atlantique Sud (1948-1949). Résultats Scientifiques, 3(5): 1-54.

Dong, D. \& Li, X. 2014. Revision of Lissoporcellana streptochiroides (Johnson, 1970) (Crustacea: Decapoda: Anomura: Porcellanidae), with description of a new species of Lissoporcellana Haig, 1978 from Beibu Bay, South China Sea. Zootaxa, 3860(5): 419-434.

García-Raso, J.E. 1987. Consideraciones taxonómicas sobre algunas especies de crustáceos Decápodos de fondos de concrecionamiento calcáreo y Posidonia oceanica: Pisidia longicornis - Pisidia longimana y Galathea bolivari - Galathea cenarroi. Investigacion Pesquera, 51(2): 277-292.

Haig, J. 1960. The Porcellanidae (Crustacea: Anomura) of the Eastern Pacific. Allan Hancock Pacific Expedition, 24: 1-440.

Haig, J. 1978. Contribution toward a revision of the porcellanid genus Porcellana (Crustacea: Decapoda: Anomura). Proceedings of the Biological Society of Washington, 91(3): 703-714.

Haworth, A.H. 1825. A new binary arrangement of the macrurous Crustacea. Philosophical Magazine, 65: 107-108.

Holthuis, L.B. 1961. Report on a collection of Crustacea Decapoda and Stomatopoda from Turkey and the Balkans. Zoologische Verhandelingen, 47: 1-67.

Koçak, C.; Kirkim, F. \& Katağan, T. 2010. Anomuran (Crustacea, Decapoda) fauna of Fethiye Bay (Turkey, eastern Mediterranean). Turkish Journal of Zoology, 34: 333-342.

Koukouras, A.; Malvidis, M. \& Noel, P.Y. 2002. The genus Pisidia Leach (Decapoda, Anomura) in the Northeastern Atlantic Ocean and the Mediterranean Sea. Crustaceana, 75(3/4): 451-463.

Leach, W.E. 1820. Galateadées. In: Dictionnaire des Sciences Naturelles. Paris, Le Normant. v. 8, p. 49-59

Linnaeus, C. 1767. Systema naturae per regna tria... 12. ed. Reformata. Holmiae, Laurentii Salvii. v. 1, pt. 2, p. 533-1327.

Manning, R.B. \& Števčić, Z. 1982. Decapod fauna of the Piran Gulf. Quaderni del Laboratorio di Tecnologia della Pesca, 3(2-5): 285-304.

Osawa, M. \& McLAughlin, P.A. 2010. Annotated checklist of anomuran decapod crustaceans of the world (exclusive of the Kiwaoidea and families (hirostylidae and Galatheidae of the Galatheoidea). Part II. Porcellanidae. The Raffles Bulletin of Zoology, 23: 109-129.

Risso, A. 1816. Histoire Naturelle des Crustacés des Environs de Nice. Paris, Librairie Grecque-Latine-Allemande. 175p.

Števčić, Z. 1990. Check-list of the Adriatic Decapoda Crustacea. Acta Adriatica, 31(1/2): 183-274.

Udekem d'Acoz, C. d'. 1995. Contribution à la connaissance des Crustacés Décapodes Helléniques II: Penaeidea, Stenopodidea, Palinuridea, Homaridea, Thalassinidea et Anomura, et note sur les Stomatopodes. Bios, Macedonia (Greece), 3: 51-77.

Udekem d'Acoz, C. d'. 1999. Inventaire et distribution des Crustacés Décapodes de l'Atlantique nord-oriental, de la Méditerranée et des eaux continentales adjacentes au nord de $25^{\circ} \mathrm{N}$. Patrimoines naturels, 40 : $1-383$.

WoRMS, 2020. WorldRegister ofMarineSpecies:Pisidia Leach, 1820. Availableat: http://www.marinespecies.org/aphia.php?p=taxdetails\&id=106837. Access in: 24/05/2020.

Zariquiey-Álvarez, R. 1951. Decapodos espanoles IV. Sobre el genero Porcellana Lamarck, 1801. Publicaciones del Instituto de Biologia Aplicada, 9: 131-139.

Zariquiey-Álvarez, R. 1968. Crustáceos decápodos Ibéricos. Investigación Pesquera, 32: 1-510. 